\title{
An investigation of the high-Al part of the Al-Pd-Ru phase diagram at 1000 and $1100{ }^{\circ} \mathrm{C}$
}

\author{
D. PAVLYUCHKOV ${ }^{1,2 *}$, B. GRUSHKO ${ }^{1}$, T.Ya. VELIKANOVA ${ }^{2}$, K. URBAN $^{1}$ \\ ${ }^{1}$ Institut für Festkörperforschung, Forschungszentrum Jülich, D-52425 Jülich, Germany \\ ${ }^{2}$ I.N. Frantsevich Institute for Problems of Materials Science, 03680 Kiev 142, Ukraine \\ * Corresponding author. Tel.: +42 2461 614693; fax: +49 2461 616444; e-mail: d.pavlyuchkov@fz-juelich.de
}

Received February 04, 2008; accepted February 17, 2008; available on-line March 31, 2008

Partial isothermal sections of the Al-Pd-Ru phase diagram at 1000 and 1100 C are presented. The Al-Pd orthorhombic $\varepsilon$-phases dissolve up to $\sim 15.5$ at.\% $\mathrm{Ru}, \mathrm{Al}_{13} \mathrm{Ru}_{4}<2.5$ at.\% $\mathrm{Pd}$ and $\mathrm{Al}_{2} \mathrm{Ru}$ up to 1 at.\% $\mathrm{Pd}$. Between 65 and 80 at.\% of Al ternary quasiperiodic icosahedral phase and four cubic phases were revealed. An additional complex cubic structure with $a \approx 3.96 \mathrm{~nm}$ was found to be formed at compositions close to those of the icosahedral phase.

Intermetallics / X-ray diffraction / Phase diagram

\section{Introduction}

Al-Pd-Ru belongs to a group of alloy systems exhibiting the formation of quasicrystals and related complex periodic intermetallics. According to the position of $\mathrm{Ru}$ in the periodic table this alloy system is linked to the recently studied $\mathrm{Al}-\mathrm{Pd}-\mathrm{Fe}$ [1-3] and $\mathrm{Al}-\mathrm{Ni}-\mathrm{Ru}[4,5]$.

The literature data on the Al-Pd-Ru alloy system are poor and limited to information on several individual phases. Earlier the formation of a cubic phase $(\mathrm{P} 23$; $\mathrm{a}=1.5540 \mathrm{~nm})$ was reported in this alloy system at $\mathrm{Al}_{68} \mathrm{Pd}_{20} \mathrm{Ru}_{12}$ [6]. Another cubic phase $(\mathrm{Fm} \overline{3} ; \quad \mathrm{a}=1.56058 \mathrm{~nm}) \quad$ was revealed at $\mathrm{Al}_{66.8} \mathrm{Pd}_{21.2} \mathrm{Ru}_{12.0}$ [7] and one more (so-called (2/1) approximant with $\mathrm{a}=2.0 \mathrm{~nm}$ ) around $\mathrm{Al}_{71} \mathrm{Pd}_{19} \mathrm{Ru}_{10}$ [8]. An icosahedral (I) quasicrystalline phase was found to be stable in the alloy $\mathrm{Al}_{72} \mathrm{Pd}_{17} \mathrm{Ru}_{11}$ [9].

In the present contribution we report the preliminary investigation of the phases and phase equilibrium in $\mathrm{Al}-\mathrm{Pd}-\mathrm{Ru}$ in the $\mathrm{Al}-\mathrm{AlPd}-\mathrm{Al}_{2} \mathrm{Ru}$ compositional triangle and the temperature range of 1000 to $1100^{\circ} \mathrm{C}$. The boundary Al-Pd phase diagram is accepted according to [10] and Al-Ru according to [11].

\section{Experimental}

Alloys were produced from the constituent elements by levitation induction melting in a water-cooled copper crucible under an Ar atmosphere. The purity of Al was $99.999 \%$, of Pd $99.95 \%$ and of Ru $99.9 \%$. The ingots were typically of about $5 \mathrm{~g}$. The samples were re-melted again if after inspection residual $\mathrm{Ru}$ was detected in the broken ingots. Parts of the samples were annealed under an Ar atmosphere or vacuum for 24 to $200 \mathrm{~h}$.

Single-phase samples were selected using powder X-ray diffraction (XRD) and scanning electron microscopy (SEM). Their compositions were examined by inductively coupled plasma optical emission spectroscopy (ICP-OES) and by energydispersive X-ray analysis (EDX) in SEM. Powder XRD was carried out in the transmission mode using $\mathrm{Cu} \mathrm{K}_{\alpha 1}$ radiation and a position-sensitive detector. The samples were also studied by electron diffraction in a transmission electron microscope (TEM) operated at $200 \mathrm{kV}$. The TEM samples were powders spread on $\mathrm{Cu}$ grids covered by carbon films. The melting temperatures of the phases were determined by differential thermal analysis (DTA) at rates of 5 to $20{ }^{\circ} \mathrm{C} / \mathrm{min}$.

\section{Results and discussion}

Intermediate phases

The above-mentioned temperature and compositional range includes the binary $\mathrm{Al}-\mathrm{Ru}$ intermediate phases $\mathrm{M}-\mathrm{Al}_{13} \mathrm{Ru}_{4}$ and $\mathrm{Al}_{2} \mathrm{Ru}$ (see Table 1). Of the Al-Pd binary phases, only AlPd is solid above $1000^{\circ} \mathrm{C}$. Isostructural congruent $\mathrm{AlPd}$ and $\mathrm{AlRu}$ (probably) form a continuous range of solid solutions naturally separating the high-Al region of $\mathrm{Al}-\mathrm{Pd}-\mathrm{Ru}$. This has not yet been studied due to 
Table 1 Crystallographic data of the $\mathrm{Al}-\mathrm{Pd}-\mathrm{Ru}$ phases mentioned in the text. The lattice parameters are given for the compositions indicated.

\begin{tabular}{|c|c|c|c|c|c|c|}
\hline \multirow{2}{*}{ Phase } & \multirow{2}{*}{ S.G. or crystal symmetry } & \multicolumn{4}{|c|}{ Lattice parameters } & \multirow{2}{*}{ For composition } \\
\hline & & $a, \mathrm{~nm}$ & $b, \mathrm{~nm}$ & $c, \mathrm{~nm}$ & $\beta,{ }^{\circ}$ & \\
\hline $\mathrm{M}-\mathrm{Al}_{13} \mathrm{Ru}_{4}$ & $C 2 / m$ & 1.5862 & 0.8188 & 1.2736 & 107.77 & \\
\hline $\mathrm{Al}_{2} \mathrm{Ru}$ & $F d d d$ & 0.8012 & 0.4717 & 0.8785 & - & \\
\hline$\beta(\mathrm{AlPd})$ & $P m \overline{3} m$ & 0.3036 & - & - & - & \\
\hline $\mathrm{C}$ & $P m \overline{3}$ & $0.77568(3)$ & - & - & - & $\mathrm{Al}_{74.4} \mathrm{Pd}_{7.5} \mathrm{Ru}_{18.1}$ \\
\hline $\mathrm{C}_{1}$ & $\operatorname{Im} \overline{3}$ & 1. 55362(14) & - & - & - & $\mathrm{Al}_{71.0} \mathrm{Pd}_{12.5} \mathrm{Ru}_{16.5}$ \\
\hline $\mathrm{C}_{2}$ & $F m \overline{3}$ & $1.55659(2)$ & - & - & - & $\mathrm{Al}_{67.7} \mathrm{Pd}_{19.7} \mathrm{Ru}_{12.6}$ \\
\hline $\mathrm{F}$ & $f c c$ & $\sim 3.97$ & - & - & - & \\
\hline$\varepsilon$ & orthorh. & $\sim 2.35$ & $\sim 1.68$ & var. $^{a}$ & & \\
\hline
\end{tabular}

${ }^{\mathrm{a}}$ The structural variants designated $\varepsilon_{6}$ and $\varepsilon_{28}$, typical of binary $\mathrm{Al}-\mathrm{Pd}$, have $c \approx 1.23 \mathrm{~nm}$ and $c \approx 5.70 \mathrm{~nm}$, respectively [10], in regular $\varepsilon_{16} c \approx 3.24 \mathrm{~nm}$. A transient structure observed around $\mathrm{Al}_{76.5} \mathrm{Pd}_{8.5} \mathrm{Ru}_{15}$ resembles $\varepsilon_{16}$ but several reflections were split.

difficulties in the equilibration of the relevant samples. For this reason the range around the $\mathrm{Al}_{3} \mathrm{Ru}_{2}$ phase was also excluded from our study. The $\mathrm{M}-\mathrm{Al}_{13} \mathrm{Ru}_{4}$ and $\mathrm{Al}_{2} \mathrm{Ru}$ phases were found to dissolve only a little of Pd: $\mathrm{Al}_{13} \mathrm{Ru}_{4}<2.5$ at.\%, $\mathrm{Al}_{2} \mathrm{Ru}$ up to 1 at. $\%$.

The Al-Pd $\varepsilon$-phases are solid below $790{ }^{\circ} \mathrm{C}[10]$, but with the increase of the $\mathrm{Ru}$ concentration this temperature increases, reaching $1030{ }^{\circ} \mathrm{C}$ at $\sim 15.5$ at.\% $\mathrm{Ru}$. Therefore this phase already appears in the $1000^{\circ} \mathrm{C}$ isothermal section (see below) in a ternary range separated from the $\mathrm{Al}-\mathrm{Pd}$ terminal. The continuity of this range was confirmed by investigation of intermediate alloys at lower temperatures and by diffraction examinations. Similarly to the structure typical of other Al-Pd-TM alloy systems [12,13], the structures observed in ternary alloys belonging to the $\varepsilon$-range exhibited variations. Around the $\mathrm{Al}_{76.5} \mathrm{Pd}_{8.5} \mathrm{Ru}_{15}$ composition, i.e. close to its high-Ru limit, transient structures resembling $\varepsilon_{16}$ were revealed by electron diffraction. A more detailed description of these structures is given in [13].

Three cubic phases isostructural to the $\mathrm{Al}-\mathrm{Pd}-\mathrm{Fe}$ $\mathrm{C}, \mathrm{C}_{1}$ and $\mathrm{C}_{2}$ phases were revealed in $\mathrm{Al}-\mathrm{Pd}-\mathrm{Ru}$. They are designated below in the same way. The electron diffraction patterns of these phases along the [110] directions are compared in Fig. 1. In addition, also the cubic "2/1 approximant" phase described in [8] was observed in our experiments but it is formed below $1000^{\circ} \mathrm{C}$. On the other hand, the existence of the cubic phase reported in [6] was not confirmed.

The primitive cubic C-phase $(P m \overline{3})$ is formed in a compositional range between about $\mathrm{Al}_{73.0} \mathrm{Pd}_{5.0} \mathrm{Ru}_{22}$ and $\mathrm{Al}_{70.5} \mathrm{Pd}_{15.0} \mathrm{Ru}_{14.5}$. Its powder XRD pattern is shown in Fig. 2a. The refined lattice parameter was $a=0.77568(3) \mathrm{nm}$ for the $\mathrm{Al}_{74.4} \mathrm{Pd}_{7.5} \mathrm{Ru}_{18.1}$ composition. The highest melting temperature of $\mathrm{C}$ is $\sim 1300^{\circ} \mathrm{C}$.

The body-centered cubic $\mathrm{C}_{1}$-phase $(\operatorname{Im} \overline{3})$ was formed below $1000^{\circ} \mathrm{C}$. The single-phase sample of $\mathrm{C}_{1}$ has not yet been obtained. The refinement of its lattice parameter was done using the diffraction data from a sample annealed at $900{ }^{\circ} \mathrm{C}$ containing some $\mathrm{Al}_{2} \mathrm{Ru}$. The value of $a=1.5532(4) \mathrm{nm}$ was obtained for $\mathrm{Al}_{71.0} \mathrm{Pd}_{12.5} \mathrm{Ru}_{16.5}$. The lattice parameter of the $\mathrm{C}_{1}$-phase is twice as large as that of the $\mathrm{C}$-phase.

The diffraction reflections typical of the $\mathrm{C}_{1}$-phase were also observed in samples of $\mathrm{Al}_{71.0} \mathrm{Pd}_{12.5} \mathrm{Ru}_{16.5}$
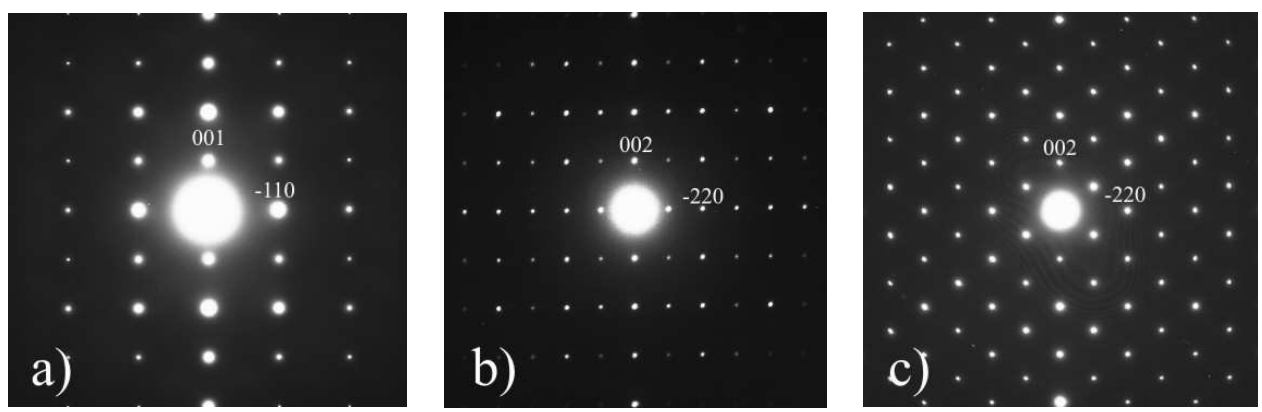

Fig. 1 Electron diffraction patterns, Z.A. $=[110]$ of the cubic phases: a) C, b) $C_{1}$ and c) $C_{2}$. 
and close compositions annealed at $1000^{\circ} \mathrm{C}$, but this was associated with transformations occurring during cooling.

The face-centered cubic $\mathrm{C}_{2}$-phase $(F m \overline{3})$ is formed in a wide compositional range between about $\mathrm{Al}_{70} \mathrm{Pd}_{15} \mathrm{Ru}_{15}$ and $\mathrm{Al}_{67} \mathrm{Pd}_{24} \mathrm{Ru}_{9}$. Its powder XRD pattern (Fig. 2b) was indexed using $a=1.55659(5) \mathrm{nm}$ for the $\mathrm{Al}_{67.7} \mathrm{Pd}_{19.7} \mathrm{Ru}_{12.6}$ composition. The highest melting temperature of $\mathrm{C}_{2}$ is $1184{ }^{\circ} \mathrm{C}$.

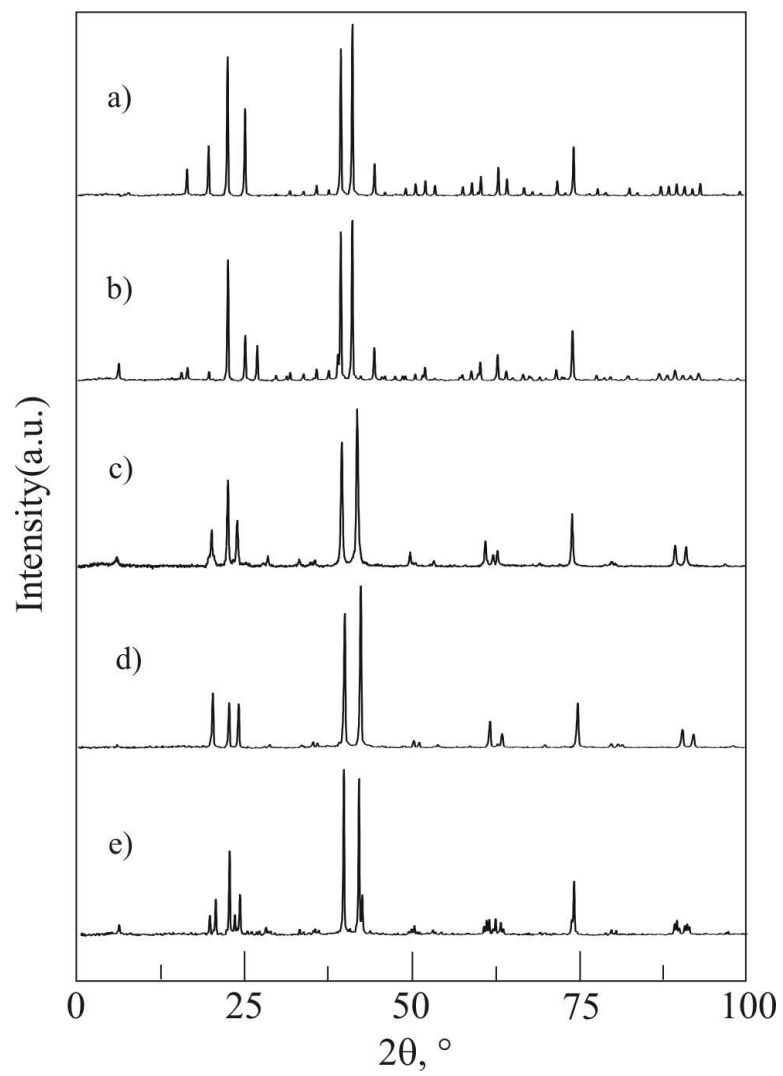

Fig. 2 Powder XRD patterns $\left(\mathrm{Cu} \mathrm{K}_{\alpha 1}\right.$ radiation) of the: a) C-phase, b) $\mathrm{C}_{2}$-phase, c) I-phase, d) I-phase of $\mathrm{Al}_{64.3} \mathrm{Cu}_{23.3} \mathrm{Ru}_{12.4}$ [14] and e) F-phase.

The stability of the ternary icosahedral quasicrystalline phase (I-phase) was confirmed. The Iphase is formed in a compositional range between $\sim \mathrm{Al}_{72.5} \mathrm{Pd}_{13} \mathrm{Ru}_{14.5}$ and $\mathrm{Al}_{70.0} \mathrm{Pd}_{19.5} \mathrm{Ru}_{10.5}$. The highest melting temperature of $\mathrm{I}$ is $1080^{\circ} \mathrm{C}$. It is isostructural to other stable I-phases in ternary alloy systems of $\mathrm{Al}$ with transition metals. The powder XRD pattern of the Al-Pd-Ru I-phase (Fig. 2c) is very similar to that of the Al-Cu-Ru I-phase published in [14] (see Fig. 2d for the $\mathrm{Al}_{64.3} \mathrm{Cu}_{23.3} \mathrm{Ru}_{12.4}$ composition). The electron diffraction pattern along the 5-fold zone axis is shown in Fig. 3b

A face-centered cubic phase with $\mathrm{a} \approx 3.96 \mathrm{~nm}$ was revealed close to the I-region around composition $\mathrm{Al}_{72.5} \mathrm{Pd}_{13.0} \mathrm{Ru}_{14.5}$. In the following it is designated $\mathrm{F}$ phase. The electron diffraction pattern along the [110] zone axis is shown in Fig. 3a. Its XRD pattern (Fig. 2e) shows a close structural relation to the I- phase. Due to such a large unit cell the reliable indexation of the powder XRD pattern is difficult and not yet complete.
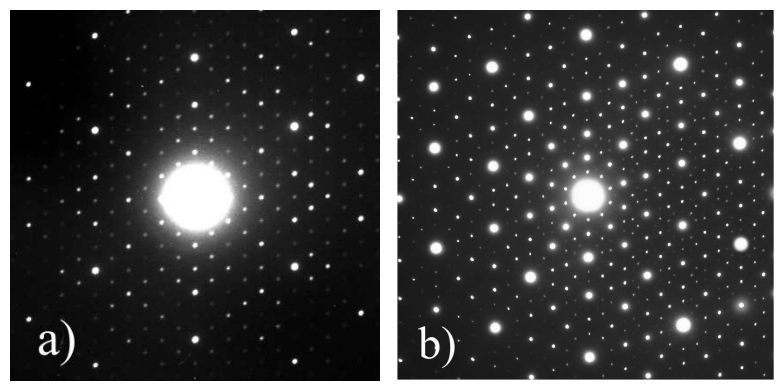

Fig. 3 Electron diffraction patterns of the: a) F-phase along the [110] zone axis and b) I-phase along the 5-fold direction.

\section{Isothermal sections}

The partial isothermal section at $1100{ }^{\circ} \mathrm{C}$ is presented in Fig. 4. In the studied compositional range the $\mathrm{Al}_{2} \mathrm{Ru}$ and $\mathrm{Al}_{13} \mathrm{Ru}_{4}$ are solid at this temperature while the region adjacent to $\mathrm{Al}-\mathrm{Pd}$ is occupied by the liquid. The limit of Al solubility in the $\beta$-phase (not shown in Fig. 4) reaches 56 at. $\%$ at 3.5 at. $\% \quad \mathrm{Pd}$.

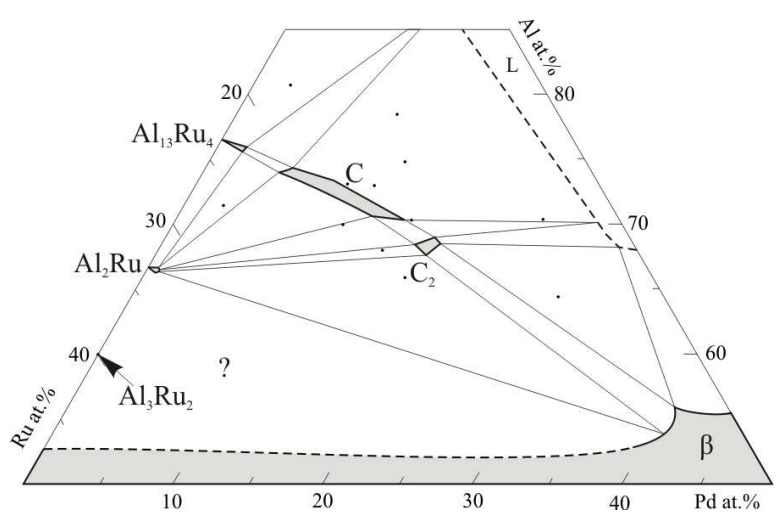

Fig. 4 Partial isothermal section of Al-Pd-Ru at $1100^{\circ} \mathrm{C}$. The compositions of the studied alloys are marked by spots, the provisional tielines are shown by dotted lines, suggested regions of homogeneity of the phases by broken lines. The liquid is designated $\mathrm{L}$, $\mathrm{M}-\mathrm{Al}_{13} \mathrm{Ru}_{4}$ is $\mathrm{M}$.

The $\mathrm{Al}_{13} \mathrm{Ru}_{4}$ and $\mathrm{Al}_{2} \mathrm{Ru}$ phases extend up to $\sim 2$ and $\sim 1$ at. $\% \mathrm{Pd}$ correspondingly. The ternary C-phase is formed in a wide range from $\sim \mathrm{Al}_{73.0} \mathrm{Pd}_{5.0} \mathrm{Ru}_{22.0}$ to $\mathrm{Al}_{70.5} \mathrm{Pd}_{15.0} \mathrm{Ru}_{14.5}$. The $\mathrm{C}_{2}$-phase is also solid at this temperature and occupies a small range around $\mathrm{Al}_{68.5} \mathrm{Pd}_{18} \mathrm{Ru}_{13.5}$. It is in equilibrium with the liquid, $\mathrm{C}$, $\mathrm{Al}_{2} \mathrm{Ru}$ and the $\beta$-phase.

The phase equilibria at $1000{ }^{\circ} \mathrm{C}$ are shown in Fig. 5. The limit of $\mathrm{Pd}$ solubility in the $\mathrm{M}-\mathrm{Al}_{13} \mathrm{Ru}_{4}$ phase increases to $\sim 2.5$ at.\%, while that of $\mathrm{Al}_{2} \mathrm{Ru}$ decreases to $\sim 0.5$ at. $\%$. Apart from $\mathrm{C}$ and $\mathrm{C}_{2}$ also $\mathrm{I}, \mathrm{F}$ and $\varepsilon$ are solid at this temperature. The regions of ternary phases are very close to each other, thus several ranges of the three-phase equilibria are 


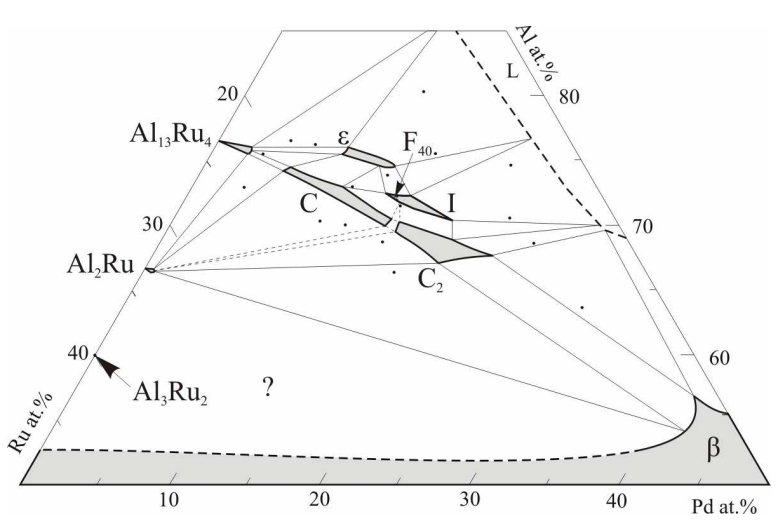

Fig. 5 Partial isothermal section of $\mathrm{Al}-\mathrm{Pd}-\mathrm{Ru}$ at $1000^{\circ} \mathrm{C}$. The compositions of the studied alloys are marked by spots, the provisional tielines are shown by dotted lines, suggested regions of homogeneity of the phases by broken lines. The liquid is designated $\mathrm{L}$, $\mathrm{M}-\mathrm{Al}_{13} \mathrm{Ru}_{4}$ is $\mathrm{M}$.

narrow. The corresponding tie-lines are shown approximately, on the basis of the results obtained from two-phase samples. The region of $\mathrm{C}_{2}$ is significantly wider than at $1100^{\circ} \mathrm{C}$ namely from $\sim \mathrm{Al}_{70.5} \mathrm{Pd}_{15.0} \mathrm{Ru}_{14.5}$ to $\mathrm{Al}_{68} \mathrm{Pd}_{23} \mathrm{Ru}_{9}$. The composition of the $\mathrm{C}$-phase varies in the range from $\mathrm{Al}_{74.5} \mathrm{Pd}_{5} \mathrm{Ru}_{20.5}$ to $\mathrm{Al}_{72} \mathrm{Pd}_{10} \mathrm{Ru}_{18}$. The I-phase is formed in the compositional range between $\sim \mathrm{Al}_{72.5} \mathrm{Pd}_{13.5} \mathrm{Ru}_{14.0}$ and $\mathrm{Al}_{70.0} \mathrm{Pd}_{19.5} \mathrm{Ru}_{10.5}$. The F-phase exists around the high$\mathrm{Ru}$ limit of the I-region. The $\varepsilon$-range extends from $\sim \mathrm{Al}_{76.0} \mathrm{Pd}_{8.5} \mathrm{Ru}_{15.5}$ to $\mathrm{Al}_{75} \mathrm{Pd}_{12} \mathrm{Ru}_{13}$.

\section{Acknowledgements}

We thank W. Reichert and M. Schmidt for technical contributions and S. Balanetskyy, M. Yurechko and S. Mi for helpful discussions.

\section{References}

[1] S. Balanetskyy, B. Grushko, E. KowalskaStrzęciwilk, T.Ya. Velikanova, K. Urban, J. Alloys Compd. 364 (2004) 166.

[2] S. Balanetskyy, B. Grushko, T. Velikanova, K. Urban, J. Alloys Compd. 368 (2004) 169.

[3] S. Balanetskyy, B. Grushko, T. Velikanova, K. Urban, J. Alloys Compd. 376 (2004) 158.

[4] S. Mi, B. Grushko, C. Dong, K. Urban, J. Alloys Compd. 351 (2002) L1.

[5] S. Mi, B. Grushko, C. Dong, K. Urban, J. Alloys Compd. 359 (2003) 193.

[6] S. Mahne, W. Steurer, Z. Kristallogr. 211 (1996) 17.

[7] K. Sugiyama, K. Hiraga, K. Saito, Mater. Sci. Eng. A 294-296 (2000) 345.

[8] T. Shibuya, T. Asao, M. Tamura, R. Tamura, S. Takeuchi, Mater. Sci. Eng. A 294-296 (2000) 61.

[9] T. Asao, R. Tamura, S. Takeuchi, Phil. Mag. Lett. (2002) 217.

[10] M. Yurechko, A. Fattah, T. Velikanova, B. Grushko, J. Alloys Compd. 329 (2001) 173.

[11] S. Mi, S. Balanetskyy, B. Grushko, Intermetallics 11 (2003) 643.

[12] M. Yurechko, B. Grushko, T.Ya. Velikanova, K. Urban, in: T.Ya. Velikanova (Ed.), Phase Diagrams in Materials Science, MSIT, Stuttgart, 2004, p. 92, http://www.matport.com/ fileadmin/contents/conferences/pdms6/pdms6_pr oceedings.pdf.

[13] S. Balanetskyy, B. Grushko, T. Velikanova, Z. Kristallogr. 219 (2004) 548.

[14] S. Mi, B. Grushko, Intermetallics 12 (2004) 425.

Proceeding of the IX International Conference on Crystal Chemistry of Intermetallic Compounds, Lviv, September 20-24, 2005. 